\title{
Departmental Elections and the Changing Landscape of French Politics
}

\author{
JAMES SHIELDS \\ School of Languages and Social Sciences, Aston University, Birmingham, UK
}

\begin{abstract}
The departmental elections of March 2015 redrew the French political landscape, setting the new terms of electoral competition in advance of the regional elections of December 2015 and, more critically, the presidential election of April-May 2017. These elections saw the far-right National Front (FN) come top in both rounds only to be outmanoeuvred by the mainstream parties and prevented from winning a single department. As a case study in vote-seat distortion, the elections highlighted a voting system effective in keeping the FN out of executive power but deficient in terms of democratic representation and inadequate as a response to the new tripartite realities of France's changing political landscape.
\end{abstract}

KEY WORDS: France, French elections, departmental elections, National Front (FN), political parties, voting system

\section{Introduction}

France has two levels of governance between the municipal and the national: departmental and regional. Of these, the much more long-serving and more deeply embedded in the French territorial map is the department. The creation of the departmental system dates back to the dawn of modern France at the Revolution of 1789, when departments replaced the Ancien Régime's feudally based provinces. Since then, the departments have remained largely unchanged and have been run by variably elected governing assemblies, becoming subject finally to direct universal suffrage (involving for the first time women voters) in 1945. By comparison, France's larger regions are a relatively recent addition to middle-level governance, having directly elected assemblies only since 1986.

France currently has 101 departments, 96 across the mainland plus Corsica (metropolitan France) and 5 overseas, each with a directly elected council. Traditionally, the department has served as the local extension of the centralized state in France, with a Parisappointed prefect representing the government and a seat of power in the local prefecture. While the prefect is charged with overseeing on-the-ground provision of state services such as police and gendarmerie, the elected departmental council has authority across a range of local government administration from social welfare, transport infrastructure and the building and maintenance of junior high schools ('collèges') to some library, touristic and emergencyservice provision. Situated between the 36500 communes that make up the municipal map of France and the (now) 13 metropolitan regions, the departments are part of a complex layering of devolved powers, budgetary competence and political influence. 
This article examines the departmental elections of 22 and 29 March 2015 and assesses the balance of political power in France at the mid-way point of the Hollande presidency. It argues that these elections set the new terms of electoral competition in France in advance of the regional elections of December 2015 and, more critically, the presidential election of April-May 2017. After a brief discussion of the electoral and political context, the voting system and the dynamics between competing parties, the results of both rounds of the elections are analysed. These reveal how the same party, the far-right National Front (FN), could win most votes over both rounds but finish with relatively few seats and control of not a single department out of 98 at stake. As a case study in vote-seat distortion, these elections highlighted a voting system effective in keeping the FN out of executive power but deficient in terms of democratic representation and inadequate as a response to the new tripartite realities of France's changing political landscape.

\section{Electoral and Political Context}

The departmental elections of March 2015 were the third major mid-term elections to be held in France since President François Hollande came to power with his Socialist government in 2012. They followed municipal elections in March 2014 that saw the Socialist Party (PS) severely defeated, with the loss to the centre-right Union for a Popular Movement (UMP) of over 150 towns, and European elections in May 2014 that saw the Socialist-led 'Union of the Left' sink to a record-low $14 \%$ of the national vote against $20.8 \%$ for the UMP. ${ }^{1}$

The particularity of those preceding elections, however, lay not in the performance of either the Socialists or the UMP. In the municipal elections, the far-right FN broke new ground by winning control of 11 towns with a collective population of over 400000 , while the European elections saw the FN emerge for the first time as the top party in France with $24.9 \%$ of the vote and 24 seats in the European Parliament as against 20 for the UMP and 13 for the 'Union of the Left'. The FN's dominance in these European elections was emphatic. It topped the poll in five of the eight Euro-constituencies, narrowly missing the lead in a sixth. It came first in 16 of the (then) 22 metropolitan regions and in 71 of the 96 departments, reaching $30-40 \%$ of the vote in 25 of these (Roger, 2014).

The political context of the March 2015 departmental elections, however, was set not just by these spectacular recent gains for the FN, with its anti-immigration, anti-European Union, anti-establishment platform (Shields, 2014). The elections were held close to the midpoint of the most unpopular French presidency on record (Kuhn, 2014), with President Hollande's campaign promises of an end to austerity, a revitalized economy and a reversal of unemployment translating into public spending cuts, economic stagnation, relentlessly high joblessness $(10.3 \%)$ and public debt exceeding $97 \%$ of GDP. ${ }^{2}$ The spectacle in national politics was of a Socialist government split over its own economic recovery programme facing a UMP riven by leadership rivalries and divided over the best strategy to adopt against the FN. Just as for the municipal and European polls of 2014, the political climate in 2015 was one of deepening voter discontent and a strong upswell of anti-elite sentiment sparing neither the governing Socialists nor, in part, the mainstream opposition UMP.

The other major feature in the timing of these departmental elections was that they took place in the wake of the terrorist attacks in Paris on the Charlie Hebdo editorial team and a Jewish supermarket in January 2015. After a brief recovery in the opinion polls following their firm response to these atrocities (Quinault Maupoil, 2015), President 
Hollande and the governing Socialists went into an electoral campaign focused not just on their failure to bring about economic recovery and reduce social inequalities but also on law and order, immigration and the security dilemmas posed by a growing Islamist terrorist threat. None of this was comfortable ground for the Socialists. It drove the electoral campaign in directions that had little or nothing to do with departmental governance, offering opportunities for political point-scoring to a UMP newly returned to the rightward-leaning leadership of Nicolas Sarkozy and, especially, to an FN under the belligerent command of Marine Le Pen.

\section{Electoral System and Party Dynamics}

Involving 98 of greater France's 101 departments, the elections of March 2015 inaugurated a new electoral map. Previously, elections at the departmental level had involved competing for seats in single-member constituencies, or 'cantons' (Gougou and Labouret, 2011). The 2015 elections redrew these constituency boundaries, cutting the number of cantons from 4035 to 2054. The other major innovation was the introduction of male-female candidate pairings ('binômes') to contest the two seats now at stake in each canton. This was a system designed to bring gender parity for the first time ever to election outcomes in France. With two candidates per party or alliance seeking election in 2054 cantons, a total of 4108 seats were to be won across the new 'departmental councils', replacing the 'general councils' that had formerly served as the departmental governing bodies emerging from cantonal elections.

Like previous cantonal elections, these new departmental elections used a two-round majoritarian system similar to that employed in elections to the National Assembly. Election on the first round required that a candidate pairing achieve over 50\% of votes cast and over $25 \%$ of the electoral register in their canton. Failing that, any pair reaching $12.5 \%$ of the electoral register would qualify for the second round, where the pair securing the largest vote would win both seats. In cases where no party or only one party cleared this hurdle, the top two would contest the run-off. All candidate pairings were to be elected for a six-year term and renewed simultaneously at the next elections in 2021 .

Three main forces competed in these elections: the Socialist Party at the centre of a 'Union of the Left', the UMP at the centre of a 'Union of the Right', and the FN. The elections were fought at ground level, with party manifestos tailored to local conditions and issues. There were, in effect, as many manifesto variants as there were departments staging elections, but some defining themes emerged to characterize the campaign priorities of the three main parties. The Socialists set a premium on improving local health care provision and upgrading educational facilities under departmental control; the UMP put an emphasis on getting claimants off welfare and back to work, on shrinking the public service wage bill by replacing only one in every two retirees, and on improving security in schools; and the FN prioritized the fight against benefit fraud, the lowering of local taxes and a steep increase in security for schools through video surveillance notably (Francetvinfo, 2015). The FN in particular showed how local issues predominate in elections at this level, as it eschewed its favoured national themes to champion the preservation of local public services, welfare support for the elderly and sound management of council finances (Front National, 2015).

Electoral strategy was dictated largely by the mechanics of the voting system. Faced with a high qualifying bar for the second round that could, on a low turnout, require up to $25 \%$ or so of votes cast, both the Socialists and the UMP sought to maximize unity and 
minimize competition within their broad centre-left and centre-right camps. Whereas the UMP achieved this to good effect, the Socialists were hampered not only by opposition on the far left but also by resistance from their former allies in Europe-Ecology-Greens (EELV), who looked mainly to the neo-Communist Left Front (comprising the Left Party (PG), the Communist Party (PCF), and various small far-left movements grouped under the banner Together!) to generate a Syriza-inspired impetus on the French left (Agence France Presse, 2015a). As a result, the Socialists were opposed by Greens or neo-Communists or both in close to half of the 2054 cantons, putting their qualification for the second round at risk in up to 400 of these (Chapuis and Faye, 2015). Meanwhile the UMP effectively restricted the competitive space across the centre-right, leaving the sovereignist Arise France (DLF) as the only minor party of any note standing outside the UMP-led alliance.

The FN, by contrast, went into these elections as a solitary force. Shunned by all other parties, denounced by Prime Minister Manuel Valls as an "immense danger" (Agence France Presse, 2015b), and deprived of the capacity to strike the sort of tactical agreements that are often imperative between the two rounds of voting, the FN finds itself at odds with the bipolarizing ethos of French elections (Knapp and Wright, 2006: 259-261). This isolation has been the key difficulty for the FN in seeking to rise above its role as spoiler and become a genuine contender for power. Following its gains in the 2014 municipal elections and unprecedented first-place performance in the European elections, the departmental elections of 2015 were to be the test of whether the FN could at last overcome this handicap. Could it for the first time win control of a department and use that as a springboard for the regional elections of December 2015 and the presidential contest of April-May 2017? More symbolically but no less significantly, could Marine Le Pen's party again lead the poll and consolidate its claim to be the 'first party of France'?

\section{Election Results and Analysis}

Table 1. Departmental Elections 2015: $1^{\text {st }}$ round (all of France)

Party/tendency

Extreme left

Left Front (FDG)

Left Party (PG)

Communist Party (PCF)

Socialist Party (PS)

Union of the Left

Left Radical Party (PRG)

Diverse Left

Europe-Ecology-Greens (EELV)

Democratic Movement (MoDem)

Union of the Centre

Union of Democrats and Independents (UDI)

Union for a Popular Movement (UMP)
Votes

14723

962384

12027

269205

2704618

1667509

62370

1383276

412729

72410

58985

263033

1337267
$\%$

0.07

4.72

0.06

1.32

13.28

8.19

0.31

6.79

2.03

0.36

0.29

1.29

6.56 
Party/tendency

Union of the Right

Arise France (DLF)

Diverse Right

National Front (FN)

Extreme Right
Votes

4256293

81981

1386638

5142241

13382
$\%$

20.89

0.40

6.81

25.24

0.07

Source: French Interior Ministry (http://www.interieur.gouv.fr/Elections/Lesresultats/Departementales/elecresult_departementales-2015/(path)/departementales2015/FE.html)

The first lesson to be drawn from these results was in the balance of political forces, with a combined left on $36.8 \%$, a combined centre-right on $36.6 \%$, and a far-right FN on $25.2 \%$ (Table 1). A more detailed look at the results by party showed a weak performance by the Left Front and a very weak performance by the Greens, confirming that the hoped-for 'Syriza effect' had not transpired on the French left. The Socialist Party and its centre-left allies, by contrast, performed more strongly than they had feared, with $21.8 \%$ providing a healthier balance sheet than the calamitous 14\% of the 2014 European elections. The Socialists averted disaster mainly through a high presence of well-entrenched local notables, but there was still a strong element of voter sanction against an unpopular Socialist Party in government which had, even without its allies, scored $24.9 \%$ and $26.7 \%$ in the corresponding (cantonal) elections of 2011 and 2008 while in opposition (France Politique, 2011; Interior Ministry, 2008).

Although the left collectively edged ahead of the centre-right, the effects of disunity were evident in the failure by centre-left and left candidates to clear the $12.5 \%$ of the electoral register and progress to the second round in over a quarter of cantons. Only two in every three Socialist candidates $(67.7 \%)$ were elected outright on the first ballot or qualified for the run-off. UMP candidates, by contrast, benefiting from their first-round coalition strategy and facing less competition on the centre-right, saw over three out of four of their candidates (76.8\%) elected or qualified for the run-off (Laurent, 2015). Though the number of seats won on the first round was relatively small, the ratio of 220 for the centre-right as against 56 for the left (110 candidate pairings to 28) told the same story of the benefits of cooperation and the costs of fragmentation (Agence France Presse, 2015c).

The cost of total isolation, on the other hand, was borne by an FN that could boast just over $58 \%$ of its candidates winning run-off qualification or election on the first round (the latter amounting to eight candidates, or four pairings, in all) (Laurent, 2015). Elections at this level have always been among the most difficult for the FN. As a party still lacking entrenchment in local and middle-level politics, the FN does not enjoy the vote premium that often accompanies local notability for the mainstream parties. Given the high run-off qualifying threshold, the opposition from all other parties, and the readiness of voters of left and centre-right to vote tactically against the FN, the prospects for Marine Le Pen's party to convert first-round strengths into second-round gains were modest. 
Yet that should not obscure those first-round strengths. With over 5.1 million votes, the FN achieved its best score to date in any election outside of the presidential, exceeding its European election score of 4.7 million votes and repeating its $25 \%$ share of the vote overall. It also reiterated its claim to be the first party of France. In terms of votes cast for candidates running on specific party labels (rather than sometimes mixed candidate pairings), the FN with its 5.1 million votes won the first round by a clear margin, ahead of the PS (3.3 million) and the UMP (3.2 million). It came first in 43 of the 98 departments, leading the poll in 320 cantons and recording its highest aggregate scores in traditional stronghold departments of the south (Var 38.9\%, Vaucluse 37.4\%, Gard 35.5\%) and developing strongholds of the north (Aisne 38.7\%, Pas-de-Calais 35.6\%, Oise 35.1\%, Haute-Marne 35.1\%). The FN also made substantial inroads in many more rural western and central departments such as Sarthe, Cher, Charente-Maritime, Indre-et-Loire, Vendée, Maine-et-Loire and other locations previously resistant to FN penetration, including even the south-western Gironde.

This performance was the more remarkable in the face of an abstention rate of just under $50 \%$ and given the FN's relative paucity of locally known candidates. In areas where the party could boast local notables, it performed especially well. Scores were particularly strong in places where the FN had secured mayors in 2014. In Le Pontet in the Vaucluse department and Fréjus in the Var (as in Vic-sur-Aisne in Aisne and Eurville-Bienville in Haute-Marne) the FN won outright in the first round; it went on to win run-offs in other towns under its municipal control: Beaucaire, Villers-Cotterêts, both cantons of HéninBeaumont and all three cantons of Béziers. These results in developing fiefdoms of FN mayors were a clear vindication of Marine Le Pen's strategy of building from the base, with many FN municipal councillors elected in March 2014 contesting cantonal seats in 2015. They also resonated with a poll in March 2015 showing satisfaction with FN mayors one year on from the municipal elections to be exceptionally high (Gaboulaud, 2015).

Polling data from these departmental elections showed the highest proportions of support for the FN to be among blue-collar workers (47\%), low-skilled employees (34\%), unemployed voters $(31 \%)$, those on precarious work contracts $(33 \%)$ and social housing tenants (34\%). Low educational attainment and low income were also strong markers of the FN vote (with $41 \%$ and $33 \%$ of these categories drawn to the party), as was lack of faith in the parties of right or left to govern (38\%) (OpinionWay, 2015).

Three main questions hung over the second round of these elections. Could the centreright coalition around the UMP capitalize on the swing against the Socialists to win perhaps as many as three-quarters of the departments? A sweeping victory would vindicate Nicolas Sarkozy's return to the UMP leadership and strengthen his prospects for the presidential primaries within his party in 2016. Could the Socialists, who went into these elections controlling 61 of the 101 departments, reduce their losses and retain some long-held strongholds? And could the FN pull off the unprecedented feat of winning even one departmental council majority and presidency? With its best hopes focused on Vaucluse, Var and Gard in the south and Aisne and Pas-de-Calais in the north, the FN had three further ambitions going into the second round: record a new electoral high at this level, increase substantially its cohort of departmental councillors across France, and demonstrate once again its nuisance power by creating difficulties for the centre-right and left alike.

Table 2. Departmental Elections 2015: $2^{\text {nd }}$ round (all of France) 


$\begin{array}{lll}\text { Party/tendency } & \text { Votes } & \text { \% } \\ \text { Left Front (FDG) } & 266896 & 1.44 \\ \text { Left Party (PG) } & 2498 & 0.01 \\ \text { Communist Party (PCF) } & 100413 & 0.54 \\ \text { Socialist Party (PS) } & 2967482 & 16.06 \\ \text { Union of the Left } & 1679890 & 9.09 \\ \text { Left Radical Party (PRG) } & 64110 & 0.35 \\ \text { Diverse Left } & 828450 & 4.48 \\ \text { Europe-Ecology-Greens (EELV) } & 29888 & 0.16 \\ \text { Democratic Movement (MoDem) } & 48038 & 0.26 \\ \text { Union of the Centre } & 39078 & 0.21 \\ \text { Union of Democrats and Independents (UDI) } & 247750 & 1.34 \\ \text { Union for a Popular Movement (UMP) } & 1596839 & 8.64 \\ \text { Union of the Right } & 5102355 & 27.61 \\ \text { Arise France (DLF) } & 9797 & 0.05 \\ \text { Diverse Right } & 1278569 & 6.92 \\ \text { National Front (FN) } & 4107891 & 22.23 \\ \text { Extreme Right } & 12851 & 0.07\end{array}$

Source: French Interior Ministry (http://www.interieur.gouv.fr/Elections/Lesresultats/Departementales/elecresult_departementales-2015/(path)/departementales2015/FE.html)

The results of the second round on 29 March (Table 2) showed a more unified vote of over $25 \%$ on the left around the Socialist Party. On the centre-right, too, the UMP consolidated its strategy of union with over $36 \%$. The elections were not quite the triumph for the UMP nor the disaster for the Socialist Party that had been anticipated - but they did deliver important lessons on the electoral costs of government unpopularity and of insufficient bloc cohesion as the Socialists lost a number of historic strongholds (Nord, Côtes d'Armor, Seine-Maritime) and highly symbolic prizes (President Hollande's base of Corrèze and Prime Minister Valls's Essonne). Opposite an ascendant 'Union of the Right', the second round confirmed the Greens as a peripheral force caught in strategic uncertainty between their old ties to the Socialists and a new potential alliance with the neo-Communist Left Front, while the Communist Party continued to live out its historic decline despite retaining control of the department of Val-de-Marne.

Again the FN stood alone, setting a new record for its performance in the second round of elections at this level with over $22 \%$ of the vote on a turnout of just under $50 \%$. When stripped out from their respective coalitions, neither the UMP's nor the Socialists' score equalled this performance. Just as the FN had, as a party, come top in the first round, it topped the second with over 4 million votes, ahead of the UMP on just under 4 million and the Socialist Party on 3.6 million (Pouchard, 2015a). 
If these had been elections won by a single party gaining most votes, the FN would have won them handsomely. But French elections do not work on that principle. In keeping with a logic that has prevailed since the foundation of the Fifth Republic in 1958, elections in France have as their primary purpose to produce strong, stable, broad-based government. For that, they demand of parties the ability to cooperate, to strike electoral bargains and form governing alliances. As a solitary force, the FN stands outside and at odds with that logic. In this sense, it suffers from what might be called the 'PCF syndrome'. The two-ballot majority system in force in these elections was that conceived for National Assembly elections in 1958, designed by incoming President Charles de Gaulle at the height of the French Communist Party's post-war power and with the intention to draw the governance of France towards the mainstream and away from the extremes, thereby preventing the PCF (then an isolated force) from coming to power alone (Knapp and Wright, 2006: 182-183).

Whatever its democratic deficiencies (Bingham Powell, 2000), this method works to stack the electoral odds against any party that stands outside and against the established party system, which in turn takes on the character of a closed 'cartel' (Katz and Mair, 2009). Thus the FN contested run-offs in over 1100 cantons, including 834 two-way contests and 273 three-way; of these it won only 22 two-way run-offs and 5 three-way. Faced with variable concentrations of support for the other parties, tactical agreements between them and widespread tactical voting, the FN was unable to increase its reserves of support enough to avoid being systematically eliminated across almost the entire departmental map. Added to the four cantons won on the first round, second-round gains gave the $\mathrm{FN}$ a total of 31 cantons out of 2054, or 62 departmental council seats out of 4108. This compared with 1138 seats for the UMP, 1008 for the PS and 379 for the centrist Union of Democrats and Independents (UDI). Even the Left Front, with just over $6 \%$ in the first round and $2 \%$ in the second, took 156 seats while the Greens with their first-round 2\% took 48 seats (Pouchard, 2015a).

Translated into control of departmental councils, these results yielded a picture that excluded the FN altogether, with the UMP winning 45 departments, the centre-leaning UDI 14, the 'diverse right' 7 and the centrist MoDem 1, while the PS won 26, the Left Radicals 3, the 'diverse left' 3, the Left Front 1 and a miscellaneous alliance 1 (Pouchard, 2015b). France thus swung from a left-dominated (61/40) to a right-dominated (67/34) departmental map. After a first round that had seemed to confirm the existence of a three-bloc party system, the bipolarization that had defined electoral competition throughout the Fifth Republic returned, eclipsing the FN entirely and exposing an unbridgeable gulf for Marine Le Pen's party between electoral support and executive power.

\section{Lessons: France's New Political Landscape}

The first major lesson of these elections, then, was in their vote-seat distortion. Despite coming first in both rounds with $25 \%$ then $22 \%$ of the vote, the FN finished with $1.5 \%$ of the seats. Though they won fewer votes than the FN, the UMP took 18 and the Socialist Party 16 times more council seats. Compare the opposite effect in the European elections of 2014, the only poll in the French electoral cycle with straight proportional representation. There, a $25 \%$ share of the vote brought the FN $32 \%$ of the seats allocated to France ( 24 out of 74 ) - a glaring exception that merely served to amplify the distortiveness of other elections.

The departmental elections also yielded broader lessons on the balance of political power in France and the dynamics of the party system and electoral competition. They left 
both the UMP and the Socialist Party facing a similar dilemma: whether to seek their alliances in the centre or push out to their far-right and far-left flanks. The UMP's union with the centre worked well to deliver victory in these elections, but could that alliance withstand Sarkozy's likely return to a hardline appeal to FN voters? The Socialists drew what secondround support they could from their historic allies on the left, the Greens and Left Front; but, given the reluctance of both to merge themselves in a Socialist-led coalition, would a push to the centre (such as that implemented by President Mitterrand at the start of his second presidential term in 1988) offer new potential for strengthening the centre-left and weakening the centre-right? These were questions set to be rehearsed again in the regional elections of December 2015 but sure to return with more urgency in the presidential campaign of spring 2017.

The final lessons of the 2015 departmental elections were about the new political landscape of France. These elections confirmed a party system fundamentally changed since the cantonal elections of 2011 and 2008 (when governing councils were renewed by half each time). In 2011, the balance of first-round strength across the Socialist-led centre-left, the UMP-led centre-right and the FN was $26.4 \%, 22.4 \%$ and $15 \%$; in 2008, it was $28.1 \%, 25.6 \%$ and $4.8 \%$. This spectacular closing of the gap with the mainstream left and right, the rise from under $5 \%$ to over $25 \%$, is the story of the FN under Marine Le Pen's leadership since January 2011.

Le Pen has made it her mission to transform the FN into a party of government, modernizing its leadership cadre and erasing the racist and anti-Semitic associations that characterized the party under her father from 1972 to 2011. This, now, is an FN equipped to compete electorally and it has momentum on its side. It has raised its tally of departmental councillors from two in 2011 to 62, marking a further stage in the party's growing institutionalization and its cultivation of a new middle-level elite. Most importantly, the FN continues to set the terms of French political debate on a host of issues (migration, security, Islamist radicalization and terrorism) that play to its policies and electoral base. And there is no current likelihood of these issues diminishing in salience nor of the FN's momentum flagging.

This article has shown how electoral mechanisms in France mask the new realities of a complex political tripartism behind a comforting illusion of continued bipolarized simplicity. But for how much longer can this illusion persist? With polls predicting Marine Le Pen's qualification for the 2017 presidential run-off at the likely expense of the Socialist candidate (Odoxa, 2016), the need on both centre-left and centre-right for an effective antiFN strategy has never been more pressing. Nor has the prospect of any such strategy's success been more open to question. 


\section{Notes}

\footnotetext{
${ }^{1}$ The UMP was to change its name shortly after these elections, becoming in May 2015 Les Républicains, The Republicans (LR).

${ }^{2}$ On unemployment, see http://www.insee.fr/fr/themes/inforapide asp $? \mathrm{id}=14 \&$ date $=20150604$; and on public debt, $\mathrm{http}: / / \mathrm{www}$. insee. $\mathrm{fr} / \mathrm{fr} / \mathrm{themes} / \mathrm{info}-$ rapide. asp? $\mathrm{id}=40 \&$ date $=20150630$.
}

\section{References}

Agence France Presse (2015a), La gauche de la gauche rêve d'une Syriza à la française, Le Point, 26 January.

Agence France Presse (2015b) Départementales: Valls dénonce un 'endormissement généralisé' face au 'danger' du FN, Le Monde, 5 March.

Agence France Presse (2015c) Départementales 2015: 220 élus de droite, 56 de gauche, 8 FN et 6 divers, Le Figaro, 23 March.

Bingham Powell, G. (2000), Elections as Instruments of Democracy: Majoritarian and Proportional Visions. New Haven: Yale University Press.

Chapuis, N. and Faye, O. (2015), Pour les élections départementales, la gauche en ordre dispersé, Le Monde, 23 February.

France Politique (2011), Elections cantonales 2011. http://www.france-politique.fr/electionscantonales-2011.htm

Francetvinfo (2015), Départementales: quels sont les programmes des partis? http://www.francetvinfo.fr/elections/departementales-quels-sont-les-programmes-despartis_850733.html.

Front National (2015), Aux élections départementales des 22 et 29 mars 2015, le Front National propose.

Gaboulaud, A. (2015), Un an après, un premier bilan des maires FN, Paris Match, 12 March.

Gougou, F. and Labouret, S. (2011), The 2011 French cantonal elections: The last voter sanction before the 2012 presidential poll, French Politics, Vol. 9, No. 4, pp. 381-403.

Interior Ministry (2008), Résultats des élections départementales 2008.

http://www.interieur.gouv.fr/Elections/Les-

resultats/Cantonales/elecresult_cantonales_2008/(path)/cantonales_2008/index.html. 
Katz, R.S. and Mair, P. (2009), The Cartel Party Thesis: A Restatement, Perspectives on Politics, Vol. 7, No. 4, pp. 753-766.

Knapp, A. and Wright V. (2006), The Government and Politics of France. 5th edn. London: Routledge.

Kuhn, R. (2014), Mister Unpopular: François Hollande and the exercise of presidential leadership 2012-14, Modern and Contemporary France, Vol. 22, No. 4, pp. 435-457.

Laurent, S. (2015), Départementales: qui a vraiment gagné le premier tour?, Le Monde, 26 March.

Odoxa (2016), Configurations souhaitées par les Français et intentions de vote pour la Présidentielle de 2017, 17 January. http://www.odoxa.fr/2017-juppe-et-macron-plebiscites/.

OpinionWay (2015), La sociologie du vote au premier tour des élections départementales 2015, 22 March. http://www.opinion-way.com/pdf/7-opinionway_pour_1_opinion_la_sociologie_du_vote_au_premier_tour_des_el....pdf.

Pouchard, A. (2015a), Après les départementales, quel est le premier parti de France?, Le Monde, 31 March.

Pouchard, A. (2015b), Qui sont les nouveaux présidents de départements?, Le Monde, 2 April.

Quinault Maupoil, T. (2015), Sondage: après l'embellie post-Charlie Hebdo, François Hollande replonge, Le Figaro, 9 February.

Roger, P. (2014), Européennes: le FN arrive en tête dans 71 départements, Le Monde, 26 May.

Shields, J. (2014), The Front National: From Systematic Opposition to Systemic Integration?, Modern and Contemporary France, Vol. 22, No. 4, pp. 491-511. 